\title{
Acute and Sub lethal Effect of Potassium Cyanide on the Behaviour and ATPase Enzyme Activity in the Freshwater Fish, Clarias gariepinus (Catfish)
}

\author{
Kadiri Oseni ${ }^{1,2^{*}}$ \\ ${ }^{1}$ Toxicology Laboratory, Department of Biochemistry, University of Benin, Benin, Edo State, \\ P.O.BOX 1154, Nigeria \\ ${ }^{2}$ Department of Food Science and Technology, Obafemi Awolowo University, PMB 13, Ile-Ife, \\ Osun State, Nigeria
}

${ }^{*}$ Corresponding author: kadirioseni@yahoo.com

Keywords: Clarias gariepinus; Toxicity; Catfish; Potassium cyanide; ATPase.

\begin{abstract}
The Present research studies the acute sub lethal toxicity of potassium cyanide $(\mathrm{KCN})$ in the fresh water, Clarias gariepinus and the effects on its behaviour and the $\mathrm{Na}^{+}-\mathrm{K}^{+}$ ATPase enzyme activity. Acute toxicity of potassium cyanide (free cyanide) to the freshwater fish was studied using static bioassay method over a period of $96 \mathrm{~h}$. Different concentrations of the toxicant $(\mathrm{KCN})$ were used and $\mathrm{LC}_{50}$ value was found to be $361 \mu \mathrm{g} / \mathrm{L}$. Behavioural changes when exposed to lethal concentration of $\mathrm{KCN}$ showed increased feed intake, cannibalism, irregular swimming activity, rapid jerk movement, aggressiveness, loss of balance, opercula movement, surface behaviour, loss of equilibrium, change in body colour and convulsion. The effect of potassium on the $\mathrm{Na}^{+}-\mathrm{K}^{+}$ATPase of various physiological tissues which includes the gill, liver, muscles and intestinal over duration of 12 h- 35 days were also studied. Cyanide intoxication resulted in marked changes in ATPase, shown by significant decrease in the enzyme activities. The result shows that ATPase enzyme together could be employed as a sensitive and useful biomarkers for cyanide pollution while the behavioural changes could be an early signal of toxicity.
\end{abstract}

\section{INTRODUCTION}

Cyanide is an extremely destructive, suicidal, homicidal and chemical agent which kills both its target and non-target-organisms when released into the environment [Dube and Hosetti, 2011; Hariharakrishnan et al., 2010). It has been reported to inhibit the mitochondrial enzyme, cytochrome oxidase in the respiratory electron transport chain, thus impairing both oxidative metabolism and the associated process of oxidative phosphorylation (Daya et al. 2000). It combines in an irreversible reaction with ferrocytochrome $\mathrm{a} / \mathrm{a}_{3}$ which leads to the inhibition of mitochondrial oxygen uptake, cellular respiration and reactions at the electron transport chain. Ferrnando et al. (1991) reported the effects of eight organochlorine pesticides on eels while also determining their $96 \mathrm{~h} \mathrm{LC}$ values and behavioural changes of the effect of the pesticides. Observation made includes anxiety, swimming disorder pattern, loss of balance, excessive mucus secretion and lightening in fish colouration. Although the modes of function of these insecticides are markedly different than potassium cyanide, behavioural changes observed are similar to this study. Bradbury and Coast (1989) reported signs of fenvelerate poisoning in fish, which included loss of schooling behaviour, swimming near the water surface, hyperactivity, erratic swimming, seizures, loss of buoyancy, elevated cough rate, increased gill mucus secretions, flaring of the gill arches, head shaking and restlessness before death.

Adenosine triphosphates (ATPase) are a set of complex set of enzymes which requires $\mathrm{Na}^{+}$ - $\mathrm{K}^{+}, \mathrm{Mg}^{2+}$ and $\mathrm{Ca}^{2+}$ ions for their activity (Carfagna et al., 1996; Praveen et al., 2012). This enzyme have requirements for $\mathrm{Na}^{+}-\mathrm{K}^{+}, \mathrm{Mg}^{2+}$ and $\mathrm{Ca}^{2+}$ ions activity and in the cleavage of ATP to ADP/AMP and inorganic phosphate (Begum, 2011), which is a vital metabolic process for the production of energy needed by cells for their metabolic processes. The major pathway for cyanide metabolism is the conversion of cyanide $(\mathrm{CN}-)$ to thiocyanate $(\mathrm{SCN}-)$, in the presence of a Sulphur 
donor by the enzyme Rhodanese (thiosulfate sulfurtransferase; EC 2.8.1.1) (Isom et al., 2010). Cyanide toxicity has been attributed to the presence of HCN derived from dissociation of the complexes that penetrate cells wall (Pablo et al., 1996). Major effects of cyanide on fish had been observed to include; growth inhibition (Dixon and Leduc, 1981), behavioural alterations (Shwetha and Hosetti, 2009), hypoxia (Dube and Hosetti, 2011) and susceptibility to predation (Eisler, 1991).

Shwetha et al. (2012) reinstated the effects of cyanide on fish and the impact it might have on human health. Consumption of cyanide caught fish or fish exposed to cyanide poses health problems to human health. Also, chronic cyanide intoxication caused by consumption of cassava, a common food product in developing countries, is the main etiological factor in the debilitating tropical ataxic neuropathy (Egekeze and Oehme, 1980). Although, cyanide is known for its potent toxic nature, it still has large applications in variety of industrial processes such as metal mining (mainly gold and silver), electroplating, steel, automobiles, carbonisation, printed circuit board manufacturing and chemical industries which invariably leads to discharge of huge quantity of cyanide (HCN/CN-) containing effluents to water bodies (Prashanth et al., 2011). During cassava processing in most communities in developing countries, large amounts of cyanoglycosides are released which are hydrolysed by plant borne enzymes, leading to cyanide concentrations in waste water as high as $200 \mathrm{mg} / \mathrm{L}$ (Siller and Winter, 1998). The peel, fibre, cassava juice and the residual water produced after the separation of starch and fibre during the fermentation and drying period rots and mixed with soil also contribute to the cyanide content of soil (Oboh et al., 2003) and water bodies respectively. Although cyanide fishing is detrimental both to aquatic life and human health, it is still a practice that is common in rural communities. Fish are gaining interest as use in the assessment of the quality of aquatic environment making them a tool of bio-indicators of environmental pollution (Prashanth and Neelagund, 2007).

The present study was carried out to investigate the influence of potassium cyanide (KCN) on the behavioural activities of the freshwater fish, Catfish, Clarias gariepinus and on the activities of adenosine triphosphates enzyme $(\mathrm{Na}+/ \mathrm{K}+$ - ATPase) within gills, liver, muscles and intestinal tissues of Clarias gariepinus.

\section{MATERIALS AND METHODS}

\subsection{Fish specimen collection and maintenance}

Cat fish, Clarias gariepinus were obtained from the fishery department of the University of Benin, Benin-Nigeria and acclimatized to laboratory conditions for one week before the start of the experiments. Only active specimens $(6.5 \pm 0.4 \mathrm{~cm}, 10.9 \pm 0.5 \mathrm{~g})$ with no signs of stress and injury were used in the study. Dechlorinated tap water (temperature $25.9 \pm 1.0{ }^{0} \mathrm{C}$, dissolved oxygen $6.5 \pm 0.5$ $\mathrm{mg} / \mathrm{l}$, carbon dioxide $6.3 \pm 0.4 \mathrm{mg} / \mathrm{L}$, hardness $23.2 \pm 3.4 \mathrm{mg} / \mathrm{l}$ as $\mathrm{CaCO}_{3}$, phosphate $0.38 \pm 0.005 \mu \mathrm{g} / \mathrm{l}$, salinity $0.01 \mathrm{ppt}$, specific gravity 0.001 , conductivity less than $10 \mu \mathrm{S} / \mathrm{cm}$ and a light period of 11 $\mathrm{h}$ /day) was used throughout the experimental period and water was renewed every $48 \mathrm{~h}$. The experimental fish were reared in aquaria of dimension $(45 \mathrm{~cm} \times 30 \times 25 \mathrm{~cm})$. Fish were fed regularly with commercial fish food pellets during acclimatization and test periods. Feeding was stopped two days prior to exposure to the test medium for acute toxicity test only. All water quality parameters (Dissolved oxygen, temperature, $\mathrm{pH}$, salinity, alkalinity, conductivity) were monitored throughout the duration of the experiment except for minimal variation tolerated by the fish in its natural habitat. After acclimation, the following steps were carried out.

\subsection{Preparation of potassium cyanide stock solution}

Stock solution was prepared by dissolving KCN (99\% purity) in double distilled water in standard volumetric flask. The required quantity of sodium cyanide was drawn from this stock solution using a micropipette. The concentration of test compounds used in short term definitive tests were between the lowest concentrations at which mortality was $100 \%$ and the highest the concentration at which mortality was $0 \%$ in the range finding tests. 


\subsection{Determinatination of $\mathrm{LC}_{50}$ of cyanide for Clarias gariepinus and observation of behavioural changes}

Ten concentrations of cyanide $(0.65,0.55,0.47,0.44,0.41,0.368,0.322,0.2,0.18$, and $0.1 \mathrm{mg} / 1)$ were prepared in 10 aquaria of different tanks of dimension $(45 \mathrm{~cm} \times 30 \times 25 \mathrm{~cm})$ containing $20 \mathrm{~L}$ of aerated dechlorinated tap water. A simultaneous control group was prepared with only aerated dechlorinated tap water after which ten healthy fish were stocked in each aquarium. Water with its fixed dose was changed daily within the period of the experiment $(96 \mathrm{~h})$. The average lethal concentration $\left(\mathrm{LC}_{50}\right)$ value of potassium cyanide to Clarias gariepinus exposed to different concentration was evaluated with consideration on the ecological importance of this specie and problems related to pollution of the aquatic environment. The mortality rate was determined at the end of 24, 48, 72 and $96 \mathrm{~h}$ and dead fish removed as and when observed. After $96 \mathrm{~h}$ from the exposure time, the percentage of fish mortality was calculated in each aquarium was according to Finney Probit Analysis (1971) and the data was evaluated using Dragstedt-Behrens equation (Carpenter, 1975). The experiment was repeated twice and $\mathrm{LC}_{50}$ value determined. After each exposure period of time $(24 \mathrm{~h}, 48 \mathrm{~h}, 36 \mathrm{~h}, 72 \mathrm{~h}$ and $96 \mathrm{~h})$, behavioural changes were also critically observed and noted.

\subsection{Determination of adenosine triphosphate (ATPase)}

To study the effect of cyanide on the enzyme activity of ATPase within the liver, muscle, gills and intestinal tissues, 40 healthy fish were stocked in each aquarium (10 fish/aquarium ) and subjected to $1 / 3 \mathrm{LC}_{50}$ of cyanide $(120.33 \mu \mathrm{g} / \mathrm{L})$ for a time duration of $24 \mathrm{~h}, 7 \mathrm{D}, 14 \mathrm{D}, 21 \mathrm{D}, 28 \mathrm{D}$ and 35D (where D means day's). Likewise, 10 fish were also stocked in an aquarium containing only $20 \mathrm{~L}$ of aerated dechlorinated tap water each for the same time period to act as control. The fish were sacrificed to collect muscle, liver, gill and intestinal tissues. Total ATPase activity was measured as the rate of release of inorganic phosphate (Samson and Quin, 1967). Each tissues was crushed with a mortar and pestle and extraction was prepared with pre cold $0.35 \mathrm{M}$ sucrose buffer $\mathrm{pH} 7.5(1: 10 \mathrm{~W} / \mathrm{V})$ and then centrifuge. Each assay was formed from $25 \mu 1$ of the tissue sample

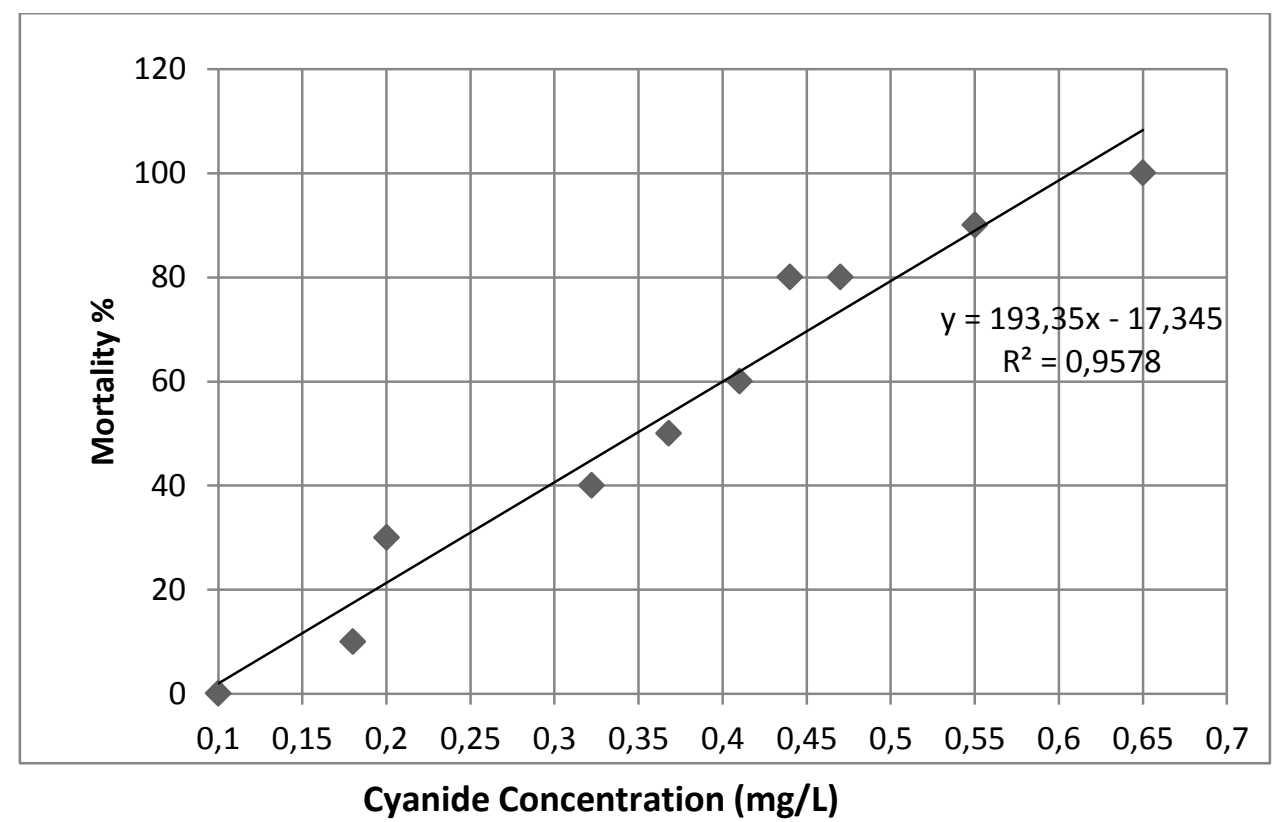

Fig. 1. Determination of $\mathrm{LC}_{50}$ of potassium cyanide in Cat Fish (Clarias gariepinus) homogenate and the supernatant was used to determine the enzyme activity in treated cyanide fish tissues by determination of inorganic phosphate in the supernatant which is liberated during the hydrolysis of the substrate adenosine triphosphate at $37^{\circ} \mathrm{C}$. The method of Lowry and Lopez (1946) was used for inorganic phosphate assay.

The detailed ATPase activities were recorded and subjected to one way analysis of variance (ANOVA) and one Duncan's significant difference test was used for mean separation. Significance level was set at $\mathrm{p}<0.05$ and $\mathrm{p}<0.01$. 


\section{RESULTS}

Toxicity Studies: Mortality was not observed in the control experiment; however, mortality increased with the increase in the concentration of the toxicant $(\mathrm{KCN})$ and the duration of exposure. The concentration at which there was zero percent mortality was $100 \mu \mathrm{g} / \mathrm{L}$ and hundred percent mortality was $650 \mu \mathrm{g} / \mathrm{L}$ (Table 1). $\mathrm{LC}_{50}$ value of cyanide was found to be $361 \mu \mathrm{g} / \mathrm{L}$. Fig. 1 shows the percentage of fish mortality that were exposed to selected concentration of cyanide in aquatic environment following the linear equation $(193.35 \mathrm{x}-17.345)$ with $\mathrm{R}^{2}=0.9578$.

Behavioural Manifestation: The behaviour and condition of fishes in both control and test experiment was observes at $12 \mathrm{~h}$ at first and $24 \mathrm{~h}$ intermittently afterward up to $96 \mathrm{~h}$ (Table 1,2$)$. There were marked behavioural changes when the test samples were exposed to potassium cyanide. Erratic swimming activity, increased surface activity, loss in equilibrium, hyperactivity, rapid swimming and opercula movement were some observed behavioural changes. In lower concentration of potassium cyanide $(100 \mu \mathrm{g} / \mathrm{L})$, the schooling behaviour of the fish was slowly disrupted with the fish showing rapid swimming than control. The fish died eventually at acute toxicity and $72 \mathrm{~h}-96 \mathrm{~h}$ exposure to the toxicant with opercula wide opened.

At longer duration of exposure to sub lethal dose of toxicant ( 35 days at $1 / 3 \mathrm{LC}_{50}$ ), it was also observed that fish exposed to cyanide showed also showed stress response which includes; gulp for air, cannibalism, swim in circle with their snout out, disorientation and increase water flow over their gills. Stunted growths were also observed. Increased in feed consumption compared to the control was observed. The increased feed intake had been reported to be an adaptation to compensate for the shortfalls in ATP production as a result of aerobic metabolism by cyanide (Okolie and Osagie, 1999). Also, Aslihan (2002) attributed membrane potential, intracellular volume and nutrient uptake to be regulated by proper function of the sodium pump. This invariably implies that disruption of the enzyme activity $(\mathrm{Na}+-\mathrm{K}+$ ATPase) responsible for the proper function of sodium pump will have effect on the nutrition of the fish which might be a reason for this increase feed intake.

Table 1: The mortality rate of the Fresh water fish (Clarias gariepinus) in 96-h at different potassium cyanide concentrations and Probit values

\begin{tabular}{|l|l|l|l|l|l|}
\hline $\begin{array}{l}\text { Concentration } \\
(\mathrm{mg} / \mathrm{L})\end{array}$ & Log Conc. $(\mu \mathrm{g} / \mathrm{L})$ & $\begin{array}{l}\text { No. of Fish } \\
\text { exposed }\end{array}$ & $\begin{array}{l}\text { No. of dead } \\
\text { Fish }\end{array}$ & $\begin{array}{l}\text { Mortality } \\
\%\end{array}$ & $\begin{array}{l}\text { Probit } \\
\text { Mortality }\end{array}$ \\
\hline 0.100 & 2.000 & 10 & 0 & 0 & 0.52 \\
\hline 0.180 & 2.256 & 10 & 1 & 10 & 1.22 \\
\hline 0.200 & 2.301 & 10 & 3 & 30 & 1.45 \\
\hline 0.322 & 2.508 & 10 & 4 & 40 & 4.21 \\
\hline 0.368 & 2.566 & 10 & 5 & 50 & 5.55 \\
\hline 0.410 & 2.613 & 10 & 6 & 60 & 6.71 \\
\hline 0.440 & 2.643 & 10 & 8 & 80 & 7.43 \\
\hline 0.470 & 2.672 & 10 & 8 & 80 & 8.04 \\
\hline 0.550 & 2.740 & 10 & 9 & 90 & 9.13 \\
\hline 0.650 & 2.813 & 10 & 10 & 100 & 9.71 \\
\hline
\end{tabular}


Table 2: Impact of Potassium cyanide $(361 \mu \mathrm{g} / \mathrm{L})$ on the behavioural patterns of Clarias gariepinus at different time duration

\begin{tabular}{llllll}
\hline \multicolumn{7}{l}{ Potassium cyanide $(361 \mu \mathrm{g} / \mathrm{L})$} & & & \\
\hline Parameters & Control & $24 \mathrm{~h}$ & $48 \mathrm{~h}$ & $72 \mathrm{~h}$ & $96 \mathrm{~h}$ \\
\hline Hyperactivity & - & - & + & ++ & +++ \\
Rate of opercula & - & + & ++ & ++ & ++ \\
activity & - & & & & \\
Loss of balance & - & - & - & + & ++++ \\
Rate of swimming & - & - & + & ++ & ++++ \\
Surface activity & - & -+ & + & + & ++ \\
Convolutions & - & - & - & - & +++ \\
\hline
\end{tabular}

Increase or decrease in the level of behavioural parameters is shown by numbers of $(+)$ sign while (-) indicates normal behavioural conditions.

ATPase Enzyme Activity: Figure 1 shows the pattern of changes in $\mathrm{Na}^{+}-\mathrm{K}^{+}$ATPase enzyme activity in the gills, liver, muscle and intestine of Clarias gariepinus exposed to potassium cyanide solution. Enzyme activity decreased significantly in cyanide exposed tissues compared to the control

Table 3. The mean activities of $\mathrm{Na}+\mathrm{K}+$ - ATPase ( $\mu$ mol Pi liberated/mg tissue) and $\%$ inhibition in different tissues of Clarias gariepinus in different times

\begin{tabular}{|l|l|l|l|l|l|l|l|}
\hline \multicolumn{7}{|c|}{ Exposure periods in days $^{\prime \mid}$ LC $_{50}(120.33 \mu \mathrm{g} / \mathrm{L})$} \\
\hline & Control & $24 \mathrm{hrs}$. & 7 days & 14 days & 21 days & 28 days & 35 days \\
\hline & 16.56 & 18.74 & 15.24 & 13.74 & 11.34 & 10.34 & 6.32 \\
\hline $\begin{array}{l}\text { Gills } \\
\text { Inhibition }\end{array}$ & & 13.16 & -7.97 & -17.03 & -31.52 & -37.56 & -61.84 \\
\hline SD & 0.50 & 0.05 & 0.10 & 0.25 & 0.45 & 0.11 & 0.24 \\
\hline Liver & 12.65 & 15.33 & 12.11 & 11.55 & 9.89 & 9.20 & 6.08 \\
\hline $\begin{array}{l}\text { \% } \\
\text { Inhibition }\end{array}$ & & 21.19 & -4.27 & -8.71 & -21.81 & -27.27 & -51.94 \\
\hline SD & 0.55 & 0.10 & 0.21 & 0.10 & 0.43 & 0.01 & 0.90 \\
\hline Muscle & 13.43 & 15.83 & 13.02 & 12.75 & 10.72 & 10.06 & 8.65 \\
\hline $\begin{array}{l}\text { \% } \\
\text { Inhibition }\end{array}$ & & 17.87 & -3.05 & -5.06 & -20.18 & -25.09 & -35.59 \\
\hline SD & 1.12 & 0.88 & 0.55 & 0.10 & 0.21 & 0.78 & 0.40 \\
\hline Intestine & 10.09 & 13.56 & 9.98 & 9.64 & 8.41 & 7.87 & 7.35 \\
\hline $\begin{array}{l}\text { \% } \\
\text { Inhibition }\end{array}$ & & 34.39 & -1.10 & -1.15 & -16.65 & -22.00 & -27.16 \\
\hline SD & 0.11 & 0.21 & 0.10 & 0.10 & 0.19 & 0.20 & 0.22 \\
\hline
\end{tabular}

\section{DISCUSSION}

The study reveals that potassium cyanide was toxic to $C$. gariepinus at sub-lethal concentration $\left(\mathrm{LC}_{50}: 120.3 \mu \mathrm{g} / \mathrm{L}\right)$ and highly toxic at lethal concentration $(650 \mu \mathrm{g} / \mathrm{L})$. Within the aquaria, the experimental results showed that when fish was subjected to varying concentration of cyanide $(100 \mu \mathrm{g} / \mathrm{L}-650 \mu \mathrm{g} / \mathrm{L})$ for a period of $96 \mathrm{~h}$, the fish revealed different behavioural mode. While the swimming pattern of fishes in the control group remains normal, fishes in the aquaria exposed to cyanide became hyperactive and restless at sub lethal concentration. At acute concentration, fishes were seen moving sluggishly in an erratic rhythm, gulping for air, losses equilibrium and convulsing prior to death. The fish very often come to the surface to gulp for aim as a result of the toxic environment which could be attributed to decreased respiratory surface a drop in the metabolic rate of the fish as observes by Shwetha and Hosetti (2009). Prashanth et al. (2011) 
reported the effect of sodium cyanide on the behavioural pattern of the freshwater fish, Labeo rohita, to be increased opercula movement, increased surface behaviour, loss of equilibrium, change in body colour, increased secretion of mucus, irregular swimming activity, rapid jerk movement, partial jerk and aggressiveness. Also, studies by Shwetha and Hosetti (2009) of the acute effects of zinc cyanide on the behaviour and oxygen consumption of the Indian major carp Cirrhinus mrigala reveals similar pattern similar to observation made in this study. Such effects may be due to osmotic stress, which affects the nervous system of the animal (Palanichamy et al., 1985). Hindrance in the functioning of the enzyme $\mathrm{AChE}$ in relation to nervous system explains probable reason for hyperexcitability and aggressiveness of the fish at the earlier stage of exposure to lethal dose of the toxicant, an observation which agrees with previous report of Deva Prakasa (2000) and Prashanth (2003). There is accumulation of acetylcholine which might prolong excitatory post synaptic potential, leading to stimulation and a block in the cholinergic system (Prashanth et al., 2011)

Enzymatic manifestation of the sodium pump is the $\mathrm{NA}^{+}, \mathrm{K}^{+}$-ATPase (Aslihan Aydemir, 2002). This membrane enzyme plays unique role in cellular function since it helps in preserving the ionic gradients, active transport of $\mathrm{Na}+$ and $\mathrm{K}+$ across cell membranes across cell membrane and thus the membrane potential and osmotic equilibrium of cell. $\mathrm{Na}^{+}-\mathrm{K}^{+}$- ATPase are cell membrane enzyme involve in the. Cyanide was found to have effect on ATPase enzyme activity. In the present study, $\mathrm{Na}^{+}-\mathrm{K}^{+}$-ATPase activity in tissue decreased significantly in liver, muscle, gills and intestine of sub lethal $\left(1 / 3 \mathrm{LC}_{50}\right)$ exposure and this decrease was duration-dependent. Maximum inhibition was observed in gill (-37.56\% and $-61.84 \%)$, followed by liver $(-27.27 \%$ and $-51.94 \%)$, Muscle ($25.09 \%$ and $35.59 \%)$ and intestine $(-22.00 \%$ and $-27.16 \%)$ on day 28 and day 35 . The effect of the toxicant was more pronounced on day $28-35$. The inhibition observed in the exposed fish tissues might be as a result of disruptions of the $\mathrm{Na}^{+}-\mathrm{K}^{+}$pump, which results in erratic entry of $\mathrm{Na}^{+}$into cell along the concentration gradient and the water molecules along the osmotic gradient which might lead to the swelling the cell membrane and rapturing. Begum (2011) coincidentally revealed that the inhibition of this enzyme by cyanide exposure leads to build up high ion concentrations in the extracellular spaces which results in the obstruction of the movement of internal destructive extra ions towards the external medium via the leakage junctions. The reduction of $\mathrm{Na}^{+} / \mathrm{K}^{+}$-ATPase may have a metabolic or ionic regulation when the fish is subjected to toxic exposure (Shwetha and Hosetti, 2012). Also, it can be said that decrease in the mean values of $\mathrm{Na}^{+} \mathrm{K}^{+}$-ATPase within the gill filaments, liver, muscles and intestine of fish are related to the metabolic activity of fish when it is subjected to sub-lethal concentration of sodium cyanide for a period of time. Further possible explanations for this observation might be due to inhibition of ATPase enzyme by the cyanide molecules, damage to cell membrane of the cyanide exposed fish which might have resulted in decrease ATP content in the respective tissues as a result of ATP leakages into the blood stream and pathological changes in tissues.

\section{CONCLUSION}

The result of this research work shows that potassium cyanide is toxic to the freshwater fish Clarias gariepinus even at both acute toxicity and sub lethal toxicity. The findings also indicate that cyanide exposure alters ATPase enzyme activity which was linked to some negative health response of the fish. Proper treatment, detoxification and disposal of cyanide containing wastes are essential for the sustenance of a clean and healthy environment. Hence, dysfunction in ATPase activity and behaviour can serve as a biomarker and index of potassium cyanide toxicity.

\section{Acknowledgements}

The author is grateful to the University of Benin, Nigeria for providing the infrastructural facilities to carry out some part of the study. I also Thank Professor N.P. Okolie for helpful discussions. 


\section{Reference}

[1] Aslihan, A.K. Na+, K+ - ATPase: A Review. 2002. Journal of Ankara Medical School, 24(2) 73-82.

[2] Barber, C. V. and Pratt, V. R. 1997. Strategies for combating cyanide fishing in Southeast Asia and beyond: Washington D .C: World Resources Institute and International Marine life Alliance.

[3] Begum, G. 2011. Organ-specific ATPase and phosphorylase enzyme activities in a food fish exposed to a carbamate insecticide and recovery response. Fish Physiology and Biochemistry, 37 (1): 61-69.

[4] Bowler R. G. 1944. The Determination of Thiocyanate in Blood Serum. Biochemical Journal, 38, 385- 388.

[5] Bradbury, S.P. and J.R. Coast, 1989. Toxicokinetics and toxicodynamics of pyrethroid insecticides in fish. Environmental Toxicology and Chemistry, 8: 373-380.

[6] Carfagna M. A., Ponsler, G. D. and Muhoberac, B. B. 1996. Inhibition of ATPase activity in rat synaptic plasma membranes by simultaneous exposure to metals. - Chem. Biol. Interact., 100: 53-65.

[7] Carpenter, PL. 1982. Immunology and Serology, 3rd ed., W. B. Saunders Co., Philadelphia, USA.

[8] Daya S., R. B. Walker and S. AnooPkumar, D. 2000. Cyanide- Induced Free Radical Production and Lipid Peroxidation in Rat Brain Homogenate is Reduced by Aspirin. Metabolic Brain Disease, 15 (3): 203-210.

[9] Deva Parkasa Raju, B. 2000. Fenvalerate induced changes in protein metabolism of fresh water fish, Tilapia mossambica. Ph. D. Thesis, S. K. University. Anantapur, A.P. India.

[10] Dixon, D.G. \& G. Leduc. 1981. Chronic cyanide poisoning of rainbow trout and its effects on growth respiration and liver histopathology. Archives of Environmental Contamination and Toxicology 10: 117-131.

[11] Dube, P.N., Hosetti, B.B. 2011: Inhibition of ATPase activity in the freshwater fish Labeo rohita (Hamilton) exposed to sodium cyanide. Toxicological Mechanisms and Methods 21(8):591-595.

[12] Egekeze, J. O., and F. W. Oehme. 1980. Cyanides and their toxicity: a literature review. Vet. $Q$. 2:104-114.

[13] Enas, M. R. 2014. Toxicity and stability of sodium cyanide in fresh water fish Nile tilapia. Water Science 28, 42-50.

[14] Eisler, R. 1991. Cyanide hazards to fish, wildlife, and invertebrates: A synoptic review. United States Fish Wildlife Service and Biology Report 85(123):1-55.

[15] Ferrando, M.D., E. Sancho and E.A. Moliner. 1991. Comparative acute toxicities of selected pesticides to Anguilla anguilla. Environmental Science and Heath, 26(5-6): 491-498.

[16] Finney, DT.1971. Probit Analysis. 3rd ed. Cambridge University Press. London.

[17] Hariharakrishnan, J, Satpute, R.M, Bhattacharya, R. 2010. Cyanide induced changes in the levels of neurotransmitters in discrete brain regions of rats and their response to oral treatment with $\alpha$-ketoglutarate. Indian Journal of Experimental Biology, 48:731-736.

[18] Isom, G.E., Borowitz .J.L, Mukhopadhyay, S. 2010. Sulfurtransferase enzymes involved in cyanide metabolism. In: Charlene AM, editor. Comprehensive Toxicology. Oxford: Elsevier. pp. $485-500$ 
[19] Lowry, O.H., Lopez, J.A., 1946. The determination of inorganic phosphorus in the presence of labile phosphate ester. Journal of Biological Chemistry, 162, 421-428.

[20] Pablo, F., Buckney, R.T., Lim, R.P., 1996. Toxicity of cyanide and iron-cyanide complexes to Australian bass Macquaria novemaculeata and black bream Acanthapagrus butcheri. Australian Journal of Ecotoxicology, 2, 75-84.

[21] Palanichamy, S., S. Arunachalam and M.P. Balasubramanian, 1985. Toxic and sublethal effect of ammonium chloride on food utilization and growth in air breathing fish Channa striatus. Proc Warm water Aquaculture Hawaii, pp: 465-480.

[22] Prashanth MS. 2003.Cypermenthrin induced physiological, biochemical and histrophalogical changes in freshwater fish, Cirrhinus mrigala. Ph.D., thesis, Karnataka University, Dharwad. India

[23] Prashanth, M.S. and Neelagund, S. E. 2007. Free cyanide- induced Biochemical changes in Nitrogen metabolism of the Indian major carp. - Cirrhinus mrigala. Journal of Basic Clinical, Physiology and Pharmacology, 8 (4): 77-287.

[24] Prashanth, M.S., Sayeswara, H.A. and Mahesh, A.G. 2011. Effect of Sodium Cyanide On Behaviour And Respiratory Surveillance In Freshwater Fish, Labeo Rohita (Hamilton). Recent Research in Science and Technology, 3(2): 24-30.

[25] Praveen, N.D., Shwetha, A., Basaling, B.H. 2012. In vivo changes in the activity of (gill, liver and muscle) ATPases from Catla catla as a response of copper cyanide intoxication. European Journal of Experimental Biology, 2 (4):1320-1325.

[26] Samson, E.F., Quin, J.D., 1967. Na+/K+activated ATPase in rat development. J. Nerochem. $14,421-427$.

[27] Shwetha A., Praveen. N. Dube and B. B. Hosetti. 2012. Effect of Exposure to Sublethal Concentrations of Zinc Cyanide on Tissue ATPase Activity in the Fresh Water Fish, Cirrhinus mrigala (Ham). Acta Zoologica Bulgarica, 64 (2): 185-190.

[28] Shwetha, A., Hosetti, B.B. 2009. Acute effects of zinc cyanide on the behaviour and oxygen consumption of the Indian major carp, Cirrhinus mrigala. World Journal of Zoology 4(3):238-246.

[29] Sille, H, Winter, J. 1998. Degradation of cyanide in agro-industrial and industrial wastewater in acidification reactor or in a single-step methane reactor by bacteria enriched from soil and peels of cassava. Applied Microbiology and Biotechnology, 50: 384-389.

[31] Oboh, G., Akindahunsi, A.A. and Oshodi, A.A.2003. Dynamics of phytate-Zn balance of fungi fermented cassava products (flour and garri). Plants Foods for Human Nutrition, 58: 1-7.

[32] Okolie N. P and K. Audu. 2004. Correlation between cyanide- induced decreases in ocular Ca2+-ATPase and lenticular opacification. Journal of Biomedical Sciences, 3 (1): 37-41.

[33] Okolie, N.P. and Osagie, A.U. Liver and kidney lesions and associated enzyme changes induced in rabbits by chronic cyanide exposure. 1999. Food Chemistry and Toxicology, 37: $745-750$. 